\title{
Chapter 9 \\ Trust, Faith, and Social Imaginary: \\ Prolegomena to an Anthropology \\ of Personhood
}

\author{
Emilio Di Somma
}

\begin{abstract}
Amidst the many problem that our societies are facing today, there is acknowledgment of the fact that the current economic system is unable to create and foster a just and stable society. This becomes increasingly true the more we continue to rely on the paradigm of the Homo economicus, which reveals itself as a fragile basis for a just and functioning society.

The paradigm of the Homo economicus does not allow us to build a workable society; but then, the first question remains, what is the fundamental feature of the Homo, what does it mean to be human? And how can we build a just and functioning society?

The theme of this work focuses on finding an answer through the paradigm of the Homo amans, that is, a paradigm in which we take into account not only human self-interest but also of those other features that are strongly linked with human life: the need for a meaning in our life, our relationship with our future and our relationship with other human beings. However, to change an anthropological paradigm, there is a necessary step that has to be addressed. To say that the paradigm of Homo economicus has been the dominant one so far, means that we have had a society that was imbued within a specific framework of customs, values, and traditions. Our society has been developed on a set of assumptions about human behavior, and on these assumptions have been developed institutions and procedures in which we trust.

The attitude of trust is the main topic of this essay. To develop a society on the paradigm of Homo amans and to further develop the debate, one should ask what kind of expectation we should encourage in people, and what should the foundations for such expectations be. What, then, is the foundation of this sensible assurance? Why do we trust people and institutions? This chapter aims to analyze this fundamental requirement for the development of any kind of society: the need for trust between persons and communities.
\end{abstract}

\footnotetext{
E. Di Somma $(\varangle)$

Evangelische Theologische Faculteit, Leuven, Belgium

e-mail: Emilio.disomma@etf.edu
} 


\subsection{From Homo Economicus to Homo Amans}

Amidst the many social and financial problems that our societies are facing today, there is growing acknowledgment of the fact that the current economic system is increasingly unable to create and foster a just and stable society. This becomes increasingly true the more we continue to rely on the paradigm of the Homo economicus, which reveals itself as a fragile basis for a just and functioning society and more of a theoretical instrument to justify the existing balance of power, with unpleasant consequences for the life of the majority of citizens. As Fleming (2017) has argued, the current social and economic landscape can be likened to the destruction left after a tsunami, where people make the catastrophic error of believing that, after the crisis, things will return to normal. All the while a new, much more catastrophic wave, is making its way toward us.

The more our societies have displayed disfunction and contradictions during crises, especially in recent years, the more the paradigm of the Homo economicus reveals itself not as an analytical tool, but as an a-rational assumption to justify the contingent, historical, structure of society. Robert H. Nelson (2001, pp. 2-8) offers us a good preliminary description of the problem we are facing. Nelson affirms that a suitable value-foundation for the market should approve the pursuit of self-interest only in those instances that it is expressed legitimately. The problem, that is a moral as well as a theological one, lies precisely in this definition of legitimization. Much like any theological/political/moral system, economics requires a normative foundation for the market that involves a dual attitude with respect to self-interest. We are presented with strong cultural inhibitions against the expression of self-interest in many areas of society, but, at the same time, strong encouragement for another powerful form of self-interest in the individual pursuit of profit that is specific to the confines of the market. According to Nelson, to avoid this conundrum, modern society developed a surprising solution: It may be that economists have themselves been acting in the requisite religious capacity. In fact, in the moment of policy making, economists try to advocate for the ethical assumptions and consequences of the system they are supporting, they do not just propose a set of technical assumptions for the scientific evaluation of reality. In this way, the role of the economist in government already assumes an ethical normative dimension. Another interpretation of a theological function in economic assumptions has been provided by D. S. Grewal (2016). He argues that the idea of self-love, channeled through commerce, producing a collectively optimal result, first appeared in seventeenth-century French debates about grace and redemption in interpretations of Augustine. Eighteenthcentury socio-economic thought made this assumption its own, transforming a theological problem into a secular model of commercial sociability. The idea that an invisible mechanism - the market functioning according to providential design makes private vices conducive to public benefit suggests an account of social order generated through essentially non-political processes.

Critiquing the paradigm of the Homo economicus, then, should be treated similarly to a theological debate, not just an economic, scientific one. While we can 
accept Mill's (1844) definition of the economic human being as a being who desires wealth, and who is capable of judging the comparative efficacy of means for obtaining that end, we should ask ourselves whether that is what it means to be Homo, to be human, and, furthermore, whether such a foundation would allow us to build a stable and just society. Seeing the economic and social upheaval of recent years, we could assume that the answer to the latter question is negative. The paradigm of the Homo economicus does not allow us to build a workable society; but then, the first question remains, what is the fundamental feature of the Homo, what does it mean to be human? And how can we build a just and functioning society?

The theme of this work focuses on finding an answer through the paradigm of the Homo amans, that is, a paradigm in which we take into account not only human self-interest (the desire for wealth and material benefits), but also those other features that are strongly linked with human life: the need for a meaning in our life, our relationship with our future and our relationship with other human beings. In this sense, then, the paradigm of the Homo amans wishes to re-discuss the fundamental concepts through which we establish a sense of personhood. While Homo economicus limits human personhood to its capacity to have and satisfy desires, the paradigm of Homo amans takes into account those elements of human life that cannot be described trough a paradigm of desires, costs, and benefits. The need for a meaning, the love toward our families, neighbors and communities, the need for hope and a clear vision of the future to foster and inspire human action, all these elements, that do exist in the life of a person, cannot be subsumed within the boundaries of the Homo economicus.

However, to change an anthropological paradigm, there is a necessary step that has to be addressed. To say that the paradigm of Homo economicus has been the dominating one so far, means that we have had a society that was imbued with a specific framework of customs, values, and traditions. Our society has been developed on a set of assumptions on human behavior and on these assumptions have been developed institutions and procedures in which we trust. The attitude of trust is the main topic of this essay. In fact, to become the foundation of a social structure, the paradigms of both Homo economicus and Homo amans need to stress the importance of actions, traditions, customs, and institutions that are supported and nurtured by the trust of the people participating in them. A social convention, or an institution, that does not have the trust of the people involved in it, is in fact unable to sustain itself to the point of becoming a historical factor. Trust, however, should not be mistaken for a feeling or sentiment. One does not need to love, or be affectionate toward the person or institution in which one trusts, one only needs the sensible expectation and assurance of a determined outcome from them. ${ }^{1}$ At the same time, however, to develop a society on the paradigm of Homo amans, and to further develop the debate, one should ask what kind of expectation we should encourage in people, and what the foundations for such expectations should be.

\footnotetext{
${ }^{1}$ The fact that the paradigm of Homo economicus could impose itself as the explanatory paradigm of modern society, thus reinforcing the model of society to which it was connected, is proof that trust does not necessarily need love.
} 
What, then, is the foundation of this sensible assurance? Why do we trust people and institutions? This chapter aims to analyze this fundamental requirement to develop any kind of society: the need for trust between persons and communities.

\subsection{The Need for Trust, a Short History of the Concept}

To be clarified and encouraged, the paradigm of Homo amans requires clarification of what trust is, and of what it means to trust someone. As Nullens and Van Nes have indicated, Homo amans needs to be founded on the three virtues of faith, hope, and love. A first tendency would be to subsume trust within the category of faith. In this sense, trust would be faith of a different order. After all, the technical definition of trust is the assured reliance of one character, ability, strength, or truth of someone or something. However, the act of trust, to be meaningful, has to rely on a sense of consistency possessed by the person (or institution/situation) in which we place our trust. We do not trust someone or something because of a future expectation, but because of the actions/events that have already happened. These allow us to build the sense of consistency and coherence we need to enter into a relation of trust. On a social level, the act of trust is possible because we all adhere to what Taylor has called a social imaginary.

As he explains in his work (Taylor 2004), we can understand a social imaginary as an epistemic structure through which human beings interpret their relations with, and within, their society. It is not only a simple scheme of relation, a collection of beliefs about the common life. It incorporates some sense of how we all fit together, both on a social and a normative plane. Through our social imaginary, we have a sense of how social things go and how should they go. This generates in us the perception of what steps are acceptable, and which ones, instead, go against social practice, both in a factual and normative way (Taylor 2004, pp. 25-6). The framework is something we are born into, it is a system in which we trust because it is imbued with a sense of coherence and consistency provided by its past. It is because things have been done in a certain way in the past that we feel compelled to keep the system going on as it has always been. It is because we engage, from the moment we are born, with related sets of values and institutions that we can perceive their history and draw on that past, which is part of our story, to build our sense of trust in them. Faith and trust, then, are certainly related, although it would be incorrect to subsume them within the same sphere of consciousness. If we espouse Taylor's theory of the social imaginary, it would be much more precise to say that trust is embedded within all the three virtues required to develop a paradigm of Homo amans.

Trust, then, is not only a necessary component of faith, but also of hope and love. We can say that all our relations require an underlying component of trust, to make sense both socially, ethically, and existentially. The necessity of a foundation of trust is something that, if we explore the history of the concept, has been evident since ancient times. Much more interesting, however, is to note how, in the classic tradition, the vocabulary for expressing faith was the same as the one used to express 
trust. In the Greco-Roman tradition, we lack a meaningful distinction between faith and trust at a conceptual/linguistic level, to the point that the same term (pistis in Greek and fides in Rome) were used in a multiplicity of instances to express different relations of trust or faith.

For examples, in the Iliad and Odyssey we see the appearance of the adjective pistos (Seidl 1952, pp. 21-32), especially in the form pistos etairos that indicates the trustworthy companion, usually the closest companions of the hero. Moreover, pistos also appears together with xenia in the context of ritualized friendships and hospitality, thus marking its centrality in the aristocratic ethos of ancient Greece. (Faraguna 2012) Another example can be found in Theognis. Being trustworthy was the quality that allowed the aristos to establish reciprocal relations of hospitality and friendship, thus marking their radical difference from the common people. Pistis was one of the fundamental qualities that made them agatos, better than the people of lower classes, apistos, who were unworthy of trust and were deceitful.

With the change of political order in the Greek polis and the establishment of democratic regimes, the concept of pistis also undergoes some etymological changes. As Faraguna tries to show us, the concept of pistis is made democratic. Its meaning transformed to indicate the fundamental prerequisite for the good functioning of society and its prosperity (Faraguna 2012, p. 363).

It becomes the fundamental attitude that makes every social activity possible. Pistis, in the Greek democratic stage, becomes the mutual trust and confidence that allows the citizens to undertake agreements in good faith and preserves the social stability of the community. Another useful source of information on this topic can be found in Angelica Taglia's (1998) work. In the context of Greek democracies, Pistis was related to peitho, the persuasion, as the fundamental pre-political quality that allowed any kind of agreement within the social body. If pistis, born from peitho, is the benevolent and rational consensus obtained through an act of persuasion, peitho, as the act in itself, is only possible and meaningful precisely because the good Greek citizen has a natural tendency to adopt pistis. Without pistis, any kind of agreement or act of persuasion becomes impossible and we regress to a state of bia, a state of violence. Pistis, therefore, not only indicated the process through which the democratic system of the polis could work properly, it also preserved its aristocratic, pre-political value. Precisely because the citizens of the polis were capable of pistis, could the polis keep itself united and function properly. In an ideal polis, pistis was the fundamental human feature that allowed any collective action (Taglia 1998, pp. 14-27).

In the Greek context, pistis was more similar to a form of knowledge - a form of awareness - than an act of abandonment. In Plato's Laws, pistis is described as the sensible acknowledgment, by the wise man, of the presence of a higher order in the cosmos, an order of which the polis is just a fraction. This rational acknowledgment would allow the wise man to guide his fellow citizens into the creation of a harmonious political order that would complement and emulate the higher order of the universe. It is the acknowledgment of, and submission to, a fundamental hypostasis that provides the existential background for everything that happens within the 
cosmos, and by consequence, would allow for the submission to the laws of the community (Taglia 1998, pp. 39-44).

It is a fundamental acknowledgment of the Greek worldview that allows the Greek citizen to make sense and find meaning in the web of social relations and institutions in which they were involved. The Greek citizen could submit to the laws of their city because they were aware that they represented, locally, a state of being affirmed throughout existence as whole. It was because things were in a certain way, that social actions should have gone in a certain way and hence, that things made sense. ${ }^{2}$

If we move our examination from the Greek context to the Roman concept of fides, we will see that the historical analysis of the idea becomes even more complex. The Roman concept of fides presented an enormous variety of fields of application spanning the categories of politics, morality, the divine sphere, and legal principles. Lombardi (1961), in his study on the Roman word-group of the term fides, described how it is impossible to determine one predominant meaning to ascribe to the constellation of contents referred by the concept.

However, a fundamental meaning of fides traced by Lombardi indicated the fundamental, practical virtue that allowed stable social relations within Roman society. Friendships, associations (socii), families, and the range of different Roman groups were sustained and sustainable because of the fundamental value of fides that allowed the single Roman citizen to navigate through the world with stable points of civil and social reference. In this sense, then, we see a similar scenario to the Greek pistis (Lombardi 1961, pp. 26-7). We see that faith is a social virtue inherent in human sociality and always connected to it. It is only because the single individual had the capacity to have faith that it was possible to establish meaningful social relations.

A similar interpretation is given by Freyburger (2009), in his work Fides, where he affirms that a fundamental meaning of confiance (trust) can be found in all the successive applications of the term, and it should, then, be considered equivalent, if not related, to the Greek pistis. Even more, says, Freyburger, we should consider the concept of trust in the Roman vocabulary as the fundamental basis that sustains all the other meanings of fides (Freyburger 2009, pp. 30-2). Building on this theory, we can affirm, then, that without this fundamental trust, we could not have all the successive acts of fides in the Roman sense. Pre-political trust was considered a necessity for any social act in Roman society.

The concept of faith/trust, independent of specific given contexts, seems to imply a relational value in the strong sense. It may be between two different people, between an institution and its members, or about the individual and the world/divine

\footnotetext{
${ }^{2}$ An example of how the law of the community must align, in a more general way, to universal laws, can be found in Sophocles' Antigone. In the play, Antigone wishes to bury his brother because of the unwritten laws of the world. While king Creon forbids it by virtue of his legal role as a king. It is true that king Creon had the legal right to order that the body of Polynices be left without burial; however, Antigone tries to remind him that there is a higher order of things to which the legal order of the polis should always conform.
} 
sphere, but faith preserved the meaning of a relationship based on a form of awareness and legitimate expectation (the degree and mix of these two aspects changing according to the context). Pistis and fides denoted trust and loyalty/promise. The basis for this sense of trust, however, had to be something solid enough to give legitimization and sustenance to the acts of relationality in such societies. To borrow Taylor's vocabulary: what was the social imaginary that gave sustenance to the ancient forms of sociality?

At this stage, Jacob Taubes comes to our aid. In his work on Pauline theology, Taubes (1993) presents the argument that the different components of society in the Roman Empire all shared a common hypostasis, a sort of hidden conspiracy. ${ }^{3}$ For Taubes, this common hypostasis was carried through in adherence to the Law, the nomos, the ius, as a foundational structure of all the different societies under the rule of Roman authority. It could be constituted specifically to suit the needs and language of a specific group (thus, for Taubes, we had a Hellenistic, Roman, and Jewish version) but all shared a foundational character through which the different groups could find a common ground of agreement. For Taubes, this is one of the most important reasons that Judaism, despite refusing to recognize the divine figure of the emperor, was still considered as religio licita and allowed to exist. It shared with Roman society the foundational acknowledgment of the nomos as hypostasis. Thus, it was still possible to integrate it within the social structure of the empire (Taubes 1993, pp. 23-5).

In Taubes' presentation of the nomos as the fundamental hypostasis of the Roman Empire, we are seeing the socio-ontological character of the relation of trust and the strong socio-existential character of the social imaginary described by Taylor.

According to Taubes, in fact, we should not interpret the law just as a legal instrument, but as a cultural/ontological awareness. It was because existence was organized in a certain way, that the authority of the city, or of the empire, made sense. It was, then, not just a legal agreement, but also an ontological understanding of the world that Romans and Greeks shared, and that Judaism, was at least not willing to call into question. We are not talking about a specific source of value, but of a more implicit acknowledgment of a whole structure of existence. In this sense, the relationship of trust always refers to a metaphysical hypostasis, a sense of implicit order in which the things that have value find their own position and structure.

With the advent of Christianity, the concept of faith began to be distinguished from the concept of trust and was used to describe only religious faith. On this topic, in her short work on the medieval concept of fides, Weijers (1977) has demonstrated how the Christian concept of faith was the result of two different processes that affected the related word-group. First, there was the expansion of the use of fides as it was developed within the Christian faith. Alongside this first process, Weijers assumes a second development. The same universal extension of the authorized use of fides as Christian faith caused the gradual decline of other meanings of the word.

\footnotetext{
${ }^{3}$ I am not using the term conspiracy in a negative sense, but in the sense of hidden or silent agreement between the parties involved.
} 
At a time when fides was primarily associated with Christian faith, the word probably grew less apt for designating quite different concepts.

Yet, the features presented above were not relinquished. The Christian individual retained a sense of trust in the institutions around him (the church, the king, etc...) because of his social/cultural framework. Of course, such frameworks were connected to the eschatological promise of the final salvation in a universal sense and, on a particular level, the Christian was enveloped in various relationships of fidelitas and confidentia that guaranteed respect of the promises made in his social context. All these relations made sense because they were connected and structured through the divine order of the universe that was emulated, on an immanent level, by the divine authority of kings, popes, and the nobility. In this sense, then, while the concept of faith became more and more connected to the religious sphere of human life, the need remained for a more fundamental concept of trust connected to a sense of the world, an ontology, if we want, that worked as the foundational binding of sociality and relationality.

\subsection{Trust, Social Imaginaries and the Origin of Personhood}

To be Homo amans we have to develop a model of society in which we evaluate human beings, not in their capacity to take rational economic decisions that aim to maximize their profit, but in their capacity to develop relationships and social bonds, together with their capacity to find meaning and seek meaning in their own life. The amans adjective can only have a positive ${ }^{4}$ meaning in the extent to which this love is directed toward other human beings, not just towards the activities and interests of an individual. As Nullens and Van Nes have argued in their essay, the Homo amans is found at the crossroads between hope, faith, and love. Only when we are able to develop a concept of society and of human being that envelops these three virtues, can we meaningfully propose a functioning moral framework and ask its implementation in society.

However, to be able to do so we should discard the concept of individual, assumed within the concept of Homo economicus and, instead take into account the concept of person. The difference, in adopting this conceptual stance, is radical. When we define a human being as an individual, we are assuming such a human being in its own separateness from the other: as a lonely monad within a cosmos that is only mechanically and instrumentally related to it. The paradigm of the Homo economicus can work with such an assumption only because it assumes that all of human relations have a utilitarian and instrumentalist nature, that a human being undertakes activities and relationships with other human beings only to gain some measure of benefit, be it pleasure or material wealth. Instead, when we take into account the being person of a human being, we assume the fact that this person is

\footnotetext{
${ }^{4}$ In the sense of being descriptive, but also in the sense of being morally right.
} 
always immersed in a web of relations that cannot be reduced just to instrumental economic calculations. A person is always socially, culturally, and historically situated; what we are as persons is the fruit of our own experiences and relationships with the human beings around us. It is always the result not only of our own actions, but also the result of the actions of other people (and of the cultural influence of society) on us. It is certainly not an easy, or comfortable process. A person may, through their own free will and capacity of self-analysis, be at odds with the society or the people around him, but this would still not deny the influences that are exercised by these cultural factors, instead, it is a re-affirmation of such influence.

In this sense, in his work on Hegel (Taylor 1975, 1979), Charles Taylor has already affirmed that, when we are talking about a person, we are talking about a culturally and historically situated phenomenon. Taylor describes how, for Hegel, the fulfilment of morality is reached when society reaches a superior state of Sittlichkeit. Taylor focuses on the fact that, when we discuss human identity, we always discuss a culturally situated phenomenon. We can think about a single individual in abstraction from his community only as an organism, but when we develop thoughts about a human being, we also think about related sets of ways to experience the world, which are culturally produced and that form his identity. What we are as human beings, Taylor says, we are only in a cultural community (Taylor 1979, pp. 85-7).

In Hegel, the concept of Sittlichkeit indicates the moral obligations we possess toward an ongoing community of which we are members. The Sittlichkeit refers to a common life that already exists. It also contributes to the constitution of the sit$t^{\prime l i c h}{ }^{5}$ of an individual. It is by virtue of this ethical order being an ongoing affair that the individual possesses these obligations. The fulfilment of these obligations is what sustains the ethical order and maintains its existence. Therefore, this ethical order is different from Moralität, in which the individual has an obligation to realize something which does not exist, that may even be in contrast with the existing moral order. The obligations provided by moralität bind the individual not by virtue of being part of a larger community, but as an individual and rational will (Hegel 1991, p. 193). For Hegel, Sittlichkeit, the world of common customs or shared life, is extremely important for the development of an ethic of duty, a philosophical trait

\footnotetext{
${ }^{5}$ With the term Sittlich, we mean the ethicality of the single individual. For a discussion of the Hegelian Sittlichkeit see: Ferrarin (2001, pp. 325-72). Also, Singer (1983, pp. 24-44). Particularly interesting is Singer's use of Hegelian categories in his criticism of the principles of the neo-liberal economy.
} 
that Taylor has inherited. The Ethos of the individual has its source in custom. ${ }^{6}$ For this reason, custom is described by Hegel as a zweite Natur, a second nature that permeates the purely natural will and creates the substance of the ethical mind. This train of thought is vital for the development of a paradigm of Homo amans as it reaffirms the fact that values, and the good, can be objectively identified outside of the subjectivity of a single individual. In the development of liberalism, which led to the development of the Homo economicus paradigm, something has value only insofar as it belongs to someone - it has no universal meaning or significance. Its own meter of judgment is exclusively what is or could be of benefit to its owner. In the Homo economicus paradigm, economic theory does not need a theory of ethics and value outside of itself; it is, in itself, a value-theory, although an extremely dysfunctional one. To affirm the paradigm of Homo amans means to go against this cultural trend. In this sense, if we affirm that the human-that-loves is found at the crossroads between hope, faith, and love, then this human being is not a lonely component, abstracted from their own community; it is immersed within it and has to recognize a good outside of themself, something that can describe as objectively good, to be in a meaningful relation with their fellow citizens and neighbors. In this sense, then, Taylor's connection of the sense of the self with the moral framework is well placed.

In his philosophical work, Taylor has discussed how this relationship influences the formation of our own identity, and he focuses especially on the historical process that allowed the development of the modern western identity (Taylor 2001). In his work, Taylor focuses on how the modern concept of identity has reached its present form and what its social function is in western civilization. He affirms that the concept of self is strictly intertwined with the concept of morality (Taylor 2001, p. 3). ${ }^{7}$ Our identity is strictly connected with the social background that surrounds us, our framework. It involves the problems of our strong evaluations, namely, the

\footnotetext{
${ }^{6}$ This because the ethos, the ethical consciousness, can be realized only in the social life and find its highest objective, in Hegel's philosophy, in the state system. Hegel aims to criticize the Kantian concept of individual morality, as it considers only the moral intention, not the actual reality of moral facts, creating a conflict between being and have-to-be, making morality like a duel in front of a mirror, in which the existence of the person is always in conflict with a tyrannical duty imposed by abstract rationality. Against this interpretation, Hegel re-affirms the importance of an ethics developed in the here and now, through the interaction of the person with the ethicality of its own community. Ethics, therefore, can be conflictual, but can also a much more pacific process of negotiating personal ethics through the ethos of the community. For this reason, Hegel denies that there is a natural law, a law that is pre-existing in respect to the laws set forth by the state. According to Hegel, morality is not a personal matter; it is not a relationship with an absolute law nor a relationship with a Destiny. Humans can achieve an ethical consciousness only through the dialectical process that starts in the category of the family, find its antithesis in civil society and is fully realized in the state, as synthesis. According to Hegel, we reach ethical achievements only through social phenomena.

${ }^{7}$ Taylor tries to understand how western modern civilization achieved its peculiar concept of the self and its (allegedly) unique features. He analyzes three great fundamental sources as the foundation of modern self-conscience: the first is the modern inwardness (sense of ourselves as beings with inner depths), the second is the affirmation of ordinary life and the third is the expressivist notion of nature as an inner moral source.
} 
fact that we engage in moral dilemmas in order to define our own identities. For Taylor, morality has two facets. An instinctive one, which is tied to our spontaneous feelings of right and wrong, and a second facet tied to a given ontology of the human. An important strand of modern consciousness has tried to diminish the ties that morality has with this second facet: mainly because of the risks involved in discussing the characteristics of this ontology of the human that history has presented to us. Taylor aims to criticize the naturalistic and secular assumption that it is possible to create a set of moral values based only on universal assumptions, abstracted from a community of reference. For Taylor, instead, it is impossible to create morality without a social framework. In addition, our strong evaluations are deeply connected with a moral source, or constitutive good, that is, a center of value which receives the greatest importance in our framework and is considered as the ultimate source of our moral reasoning (Taylor 2001, pp. 28-32).

As Abbey (2004) has argued, Charles Taylor is attempting to open up a nonanthropocentric perspective on the good, to allow us to see the sovereignty of good over the moral agent. In moving the philosophical argument in this direction, Taylor's philosophy aims to be explicitly a retrieval of this non-anthropocentric perspective that philosophy, since the Enlightenment, has been motivated to occlude. To achieve this outcome, Taylor has to postulate, in my opinion correctly, a strong connection between the source of moral good and the individual identity connected to it.

At this stage, we can return to Taylor's concept of social imaginary as a foundation for building the necessary trust to create a coherent and functioning society. I have referred to this concept of social imaginary several times in the previous pages. With this concept, to which Taylor will dedicate a whole work (Taylor 2004), he indicates something much more broad and deeper than just an intellectual or mental scheme. A social imaginary is more like a common framework or reference for explaining and justifying social existence. It is different from a social theory, according to Taylor, because of three fundamental features:

1. it is not used to explain social realities; it is used, instead, to imagine social surroundings. It does not necessarily work through theoretical categories, instead it relies also on images stories and legends that are relevant to the community. It relies then, equally on feelings and sentiments as much as on intellectual faculties.

2. A theory is, usually, the field of a restricted circle of experts. A social imaginary, instead, is available to all members of the community. It is shared by all the persons belonging to the same society.

3. A social imaginary is tied to common sense more than to complex knowledge. It instils, within the community, a wider sense of legitimacy for social practices and institutions; it allows for customs, traditions, and institutions to make sense within a community (Taylor 2004, pp. 23-7).

A social imaginary, however, is never a simple thing. Instead, it reveals various levels of complexity. It involves a sense of normal and legitimate expectation around our own social actions and the actions of the people that participate in society along 
with us. It provides a sense of normalcy and meaning on how we all fit together in our common practices, both at a factual and at a normative level. Not only, then, does it make sense of our immediate particular practices, it also offers a wider metaphysical or moral background through which we make sense of how we stand in relation to each other, how we relate to each other and with other groups.

The relationship between this background and our practices is not one-sided. A social imaginary is not a cultural, untouchable, authority that prescribes all of our actions. Instead, it is a framework of reference that help us to make sense of our relations and actions towards other human beings. However, such understanding, while influencing our actions, is also is also influenced and reinforced (or questioned) by the actions themselves.

It can be likened, as Descombes (1994) implies, although not referring directly to the concept of social imaginary, to Hegel's objective spirit. According to Descombes, Taylor retains a sort of positivist Hegelianism, a baggage of Hegelian concepts freed from their theological/ontological value and now used as sociological instruments. The fundamental assumption behind Taylor's Hegelian interpretation of social events is that social life is not reducible to the necessities of common life, but that it has a meaning. The individuals that partake in any social life derive a fundamental something, a meaningfulness, from it. The problem, then, would be to understand properly the effective social reality of this meaningfulness, defined by Descombes as the objective spirit of a society, in a Hegelian sense. He affirms that to understand Taylor's philosophical proposal correctly, we must interpret this concept of objective spirit as a sharable state of mind or a rule to follow. That is, a condition for the social exercise of intelligent activity, a condition to which individuals would be subject in a manner that does not require their expressed consent. According to Descombes, Taylor's strategy is twofold, he shows how any social practice presupposes common (as opposed to merely shared) meaning. In addition, he argues that institutions express the ideas and meanings mentioned that resemble the Hegelian objective spirit. The functions of institutions, therefore, can be compared, to those of a language (Descombes 1994, pp. 97-106). We could interpret the concept of social imaginary as the full, conceptual, inheritance of the Hegelian concept of objective spirit and its complete assimilation in Taylor's social theory, although devoid of any ontological cosmic reference to the absolute spirit. The social imaginary, then, would an immanent objective spirit, a framework of reference that does not need, necessarily, a connection with an absolute being; although many social imaginaries in western history did rely on this connection. ${ }^{8}$

The social imaginary can be described as one of the cultural-ontological foundations of trust. We can develop a sense of trust in the institutions and traditions in our surroundings because, as I argued in the previous pages, we can base our trust on a

\footnotetext{
${ }^{8}$ The topic of debate, at this point, would be to evaluate the eventual success or lack of it of such social imaginaries. Did social imaginaries connected to a spiritual source achieve a stable and just society more successfully than those social imaginaries that did not? This chapter, obviously, does not aim to answer this question, or even debate it, but the question is left here to stimulate the reader's thoughts.
} 
sense of consistency. The social imaginary is the foundation on which this sense of consistency is built. Therefore, if the Homo amans can be so only socially, that is, within a society and a set of shared values with his community of reference, then we need to investigate how we can structure a new social imaginary on which the relation of trust between persons and between persons and institutions, within a community, can be born and developed. It is only because we trust other human beings that we can entertain them in social relations. It is only because we start with a fundamental attitude of trust towards our neighbors, that we do not fear to relate with them and have relationships with other human beings. It is vital, then, to provide a strong sense of consistency and meaning on which we can build such trust and foster it in our own communities.

\subsection{Trust, Faith and Homo Amans, the Need for a New Social Imaginary}

In the Reith Lectures of 2002, philosopher Onora O'Neill admitted that our society is facing a crisis of trust. I believe it is not hard to find evidence that confirms this in our current social landscape. The crisis of trust does not involve just the loss of legitimacy and the increase of suspicion with which citizens look upon their governing institutions. It involves the whole of a society that is becoming increasingly fractured by more and more restricting boundaries, tied by subjective identities and the wishes of restricted groups. Today, in western societies, we witness the increasing impossibility of the citizenry as a whole standing together behind a common position, political or moral.

It becomes immediately clear that, clear though the concept may be, the concrete reality of the act of trust cannot be so easily identified. So far, I have described trust as the necessary foundation for building any successive relational act. In this sense, love, hope, and faith would be possible only when trust has been built into a relationship.

However, when we want to examine the concrete relationship between these concepts (and in so doing, how they reveal themselves in human action and in social/ cultural reality), the phenomenon appears much less clear. It may well be a chicken or egg dilemma: does sociality starts with trust (that then allows successive relational acts that foster the virtues of hope, faith, and love) or are those virtues practiced on a gradual scale that can then give birth to social customs and wider relational forms?

The only thing we can be sure of is that we are born when the social game has already started and is ongoing. Our personal social interactions may well start with our birth, but society (and sociality) is already in progress when we make our appearance in the play. In this sense, it may be in our more immediate interest to understand the ongoing rules of meaningful social interaction, rather than focus on the origin of said interaction. 
The ongoing rule of this game, as we have assumed at the beginning of this essay and building on Taylor's work, is that a social paradigm is built on a social imaginary. I believe the best definition of social imaginary, as suggested by Taylor, would be that of epistemic structure. In A Secular Age, Taylor further expands the concept by also describing its role in developing the modern, scientific and liberal social imaginaries. It was the transformation of the social imaginary that allowed the birth of modernity. According to Taylor, the processes involved in the transformation of social imaginary are not necessarily linear and do not need, at least at the moment of their origin, institutional support. A social imaginary can start as a set of claims belonging to a restricted niche group and then expand to embrace the whole community. This is what happened in the modern age, for example, with the theories of Locke and Grotius. Thanks to Locke's philosophy of nature and Grotius' view of normative order, modern society acquired, slowly but steadily, the sensibility that society exists for the mutual benefit of the individuals and to protect their rights. A new picture of society was, thus, developed, one in which individuals come together to form a political entity against certain pre-existing moral backgrounds and with particular ends in view. In modernity, the moral background was one of natural rights, where people already have certain moral obligations toward each other, while the ends sought were certain common benefits, of which security was the most important. In the specific case of modernity, the new social structure - with its underlying concept of moral order - influenced the development of modern society along three axes. First, in extension - starting from a restricted niche of thinkers and philosophers, it influenced the social discourse in other niches until it encompassed the whole of western society. Second, in intensity - the demands people made on society became more complex and ramified. And lastly, in the demands society itself made on the people - while making our demands, it is incumbent on us to take some kind of action or attitude as a counterpart, as a duty. These three axes of modification also involved a separation of the modern moral order from any kind of connection to a transcendent source of good. The pre-modern understandings of moral order (egalitarian, such as the law of the people, or hierarchical, inspired from the platonic/Aristotelian philosophy) were connected to a transcendent order of the cosmos, such that a breach of the law was equivalent to a breach of the order of the cosmos itself. According to Taylor, the modern moral order had no such ontic or cosmic reference, it was an order made for the here and now (Taylor 2007, pp. 4-15). ${ }^{9}$

It is within this enormous transformation of social imaginary that Taylor identifies three, very specific, forms of social self-understanding as social imaginaries born from Locke's and Grotius' theories of moral order. The first one has been Economy, which came to be considered as an objectified reality. Taylor finds the greatest example of this new development in Adam Smith's theory of the invisible

\footnotetext{
${ }^{9}$ The difference is a great one, while the previous concept of moral order stated that the individual is complementary to the whole, so that the first task of the individual is to work to preserve the community, with the modern concept of people and moral order, the relationship is reversed. It is now the individual that should be preserved, and the purpose of the society is to guarantee his safety.
} 
hand. Where economy becomes the fundamental model of society, ${ }^{10}$ not only as a metaphor, but also as the dominant end of human activity.

The second social imaginary was the public sphere. This concept indicates not only the official sphere of government, but communication in society as a whole. The public sphere is a common space in which members of society meet through a variety of media. In addition, communication is not only present between members of society, but also between media themselves. The public sphere is so important that, even in conditions where it is controlled or abolished, its existence is still faked to retain control over the population. We have come to consider this space as distinct from the political space, and, at the same time, a benchmark of legitimacy for the political authority (Taylor 2007, pp. 86-99). ${ }^{11}$

The final social imaginary has been popular sovereignty. The two great revolutions of the eighteenth century (French and American) created the conditions for the interplay of social imaginaries, new and traditional, that helped determine their respective courses and culminated with the affirmation of popular sovereignty. According to Taylor, revolutionary brutality made it possible for ideologies that found support only in minor circles (such as the republican theory of Rousseau), to spread among the people. This generated the development of the new social imaginary in which the legitimization of the power resides in the population (Taylor 2007, pp. 109-41). In this way, we shifted from a vertical society to a horizontal society. ${ }^{12}$

To build a society on the paradigm of Homo amans, then, we should, with plausibility, assume that western society has to go through the same, painful, process of transformation. The plight of our contemporary society, and the social crises it is currently facing, can no longer be addressed through the modern liberal presuppositions of an absolute individual, completely independent and separate from other human beings and from its societies of reference. It is born out of a cultural assumption that spatial and temporal separations are an absolute that has to be taken for granted. That our physical separateness from our neighbors translates into an

\footnotetext{
${ }^{10}$ Economy was obviously linked with the self-understanding of polite civilizations as grounded in a commercial society. However, the eighteenth century adds an appreciation of the way human life is designed to produce mutual benefit. Emphasis is put on the invisible hand factor. With this, Taylor means the theory in which we are supposed to be programmed to commit to specific actions and attitudes that systematically have beneficial results for the general happiness. Adam Smith, in the Wealth of Nations, provide us with the better example of this mechanism. This new understanding of providence is already evident in Locke's formulation of natural law theory in the Second Treatise; we can see how much importance the economic dimension is taking on in this new notion of order. The two main goals of an organized society become, therefore, security and economic prosperity. This leads to a study of economics as an objectified reality with its laws and mechanisms, as an object of science; but this also determines the complete independence of economy from the political plane.

${ }^{11}$ Taylor describe the public sphere as a meta-topical common space; a topical common space is a space where people come together in a common act of focus for whatever purpose (a ritual, a conversation, the celebration of a major event, etc...). A meta-topical common space transcends such topical spaces; it knits together a plurality of such spaces into one larger space of non-assembly.

${ }^{12}$ Taylor examines the shift that led to a society in which the order was guaranteed by a transcendental order, to a society in which the order is achieved by common action, as in the secular age.
} 
impossibility of developing a relationship with them, that it is impossible to build a bridge over such division; or that, maybe, this bridge has always existed, we have just conveniently ignored it to avoid the responsibility it brings with it. Every cultural framework always develops a metaphysical image of the world, a social imaginary, which helps society to structure its own political and social institutions. The ontology of the world goes hand in hand with what a society consider acceptable as political/ethical organization. In this sense, then, if we wish to build a society on the paradigm of Homo amans and re-build a sense of trust within our own communities, we cannot simply acknowledge that faith, hope, and love can be good virtues. We have to find the courage to affirm their objective goodness, that they can be good virtues to be cultivated by all who have a stake in our society. We need to reclaim, then, a social imaginary that can be a stable foundation for the Homo amans.

\section{References}

Abbey, R. 2004. Charles Taylor. Cambridge: Cambridge University Press.

Descombes, V. 1994. Is There an Objective Spirit? In Philosophy in an Age of Pluralism: The Philosophy of Charles Taylor in Question, ed. J. Tully, 96-118. Cambridge: Cambridge University Press.

Faraguna, M. 2012. Pistis and Apistia: Aspects of the Development of Social and Economic Relations in Classical Greece. Mediterraneo Antico, 15(1-2), 355-374.

Ferrarin, A. 2001. Hegel and Aristotle. Cambridge: Cambridge University Press.

Fleming, P. 2017. The Death of Homo Economicus: Work, Debt and the Myth of Endless Accumulation. London: Pluto Press.

Freyburger, G. 2009. Fides: Étude sémantique et religieuse depuis les origins jusqu'à l'époque augustéenne. Paris: Les Belles Lettres.

Grewal, D.S. 2016. The Political Theology of Laissez-Faire: From Philia to Self-Love. Political Theology 17 (5): 417-433.

Hegel, G.W.F. 1991. Elements of the Philosophy of Right. Transl. H.B. Nisbet. Cambridge: Cambridge University Press.

Lombardi, L. 1961. Dalla Fides alla Bona Fides. Milan: Giuffré.

Mill, J.S. 1844. Essays on Some Unsettled Questions of Political Economy. London: Parker.

Nelson, R.H. 2001. Economics as Religion: From Samuelson to Chicago and Beyond. State College: Pennsylvania State University Press.

Seidl, E. 1952. Pistis in der griechischen Literatur bis zur Zeit der Peripatos. PhD diss. University of Innsbruck.

Singer, P. 1983. Hegel. Oxford: Oxford University Press.

Taglia, A. 1998. Il Concetto di Pistis in Platone. Florence: Le Lettere.

Taubes, J. 1993. The Political Theology of Paul. Transl. D. Hollander. Stanford: Stanford University Press.

Taylor, C. 1975. Hegel. Cambridge: Cambridge University Press. 1979. Hegel and Modern Society. London: Cambridge University Press.

. 2001. Sources of The Self: The Making of Modern Identity. Cambridge, MA: Harvard University Press.

. 2004. Modern Social Imaginaries. London: Duke University Press.

-2004. Modern Social Imaginaries. London: D

Weijers, Olga. 1977. Some Notes on Fides and Related Words. Medieval Latin, Archivum Latinitatis medii aevi 40: 77-102. 
Open Access This chapter is licensed under the terms of the Creative Commons Attribution 4.0 International License (http://creativecommons.org/licenses/by/4.0/), which permits use, sharing, adaptation, distribution and reproduction in any medium or format, as long as you give appropriate credit to the original author(s) and the source, provide a link to the Creative Commons license and indicate if changes were made.

The images or other third party material in this chapter are included in the chapter's Creative Commons license, unless indicated otherwise in a credit line to the material. If material is not included in the chapter's Creative Commons license and your intended use is not permitted by statutory regulation or exceeds the permitted use, you will need to obtain permission directly from the copyright holder. 